\title{
Capitalism, Crisis, and Alternative System Seeking
}

Gülten Üstüntağ

Middle East Technical University (METU)

\section{Review article of three books:}

1. Adam Hanieh, Capitalism and Class in the Gulf Arab States (New York: Palgrave Macmillan, 2011, 266pp., USD 90, hardcover)

2. John Bellamy Foster and Robert W. McChesney, The Endless Crisis: How Monopoly Finance Capital Produces Stagnation and Upheaval from the USA to China (New York: Monthly Review Press, 2012, 227pp., USD 18.08, hardcover)

3. Samir Amin, Ending the Crisis of Capitalism or Ending Capitalism? (New York: Pambazuka Press, 2011, 208pp., USD 25.16, paperback)

The current economic stagnation, which some have considered to be in existence since the 1970s and that peaked with the collapse of the financial markets in 2008 (Amin, 2011, p.3) has engendered discussions about the rise of new ideologies and regional-global powers as an alternative to the capitalist order led by the United States (US). Several questions arise regarding reshaping the capitalist system in the face of emerging powers such as China and those in the Persian Gulf and Latin America, and regarding assisting the recovery of the current system: Is the global capitalist system facing collapse? What do financialization and monopolization mean in the capitalist system? What kind of new formations does a crisis of capitalism lead to?

Three books aim at giving satisfying answers to these questions from different perspectives: Adam Hanieh's Capitalism and Class in the Gulf Arab States; ${ }^{1}$ John Bellamy Foster and Robert W. McChesney's The Endless Crisis: How Monopoly-Finance Capital Produces Stagnation and Upheaval from the USA to China; ${ }^{2}$ and Samir Amin's Ending the Crisis of Capitalism or Ending Capitalism? ${ }^{3}$ All authors question the sustainability of the current global economic order in the face of a crisis triggered by the actions of current system actors that have the capacity to bring an end to the capitalist system through emerging powers, regions, and/or ideologies.

\section{Capitalism and Class in the Gulf Arab States, Adam Hanieh}

From the Marxist perspective, Adam Hanieh's book discusses the steps towards the

Gülten Üstüntağ, Special Student in the PhD program, Department of International Relations, Middle East Technical University. Email: gultenustundag24@gmail.com.

Adam Hanieh, Capitalism and Class in the Gulf Arab States (New York: Palgrave Macmillan, 2011).

2 John Bellamy Foster and Robert W. McChesney, The Endless Crisis How Monopoly-Finance Capital Produces Stagnation and Upheaval from the USA to China (New York: Monthly Review Press, 2012).

3 Samir Amin, Ending the Crisis of Capitalism or Ending Capitalism? (New York: Pambazuka Press, 2011). 
internationalization and financialization ${ }^{4}$ of capital in the Gulf Cooperation Council (GCC) and the creation of a state-backed trading class in the region as an agent of capitalism. It also discusses competition among the superpowers and capitalist countries for the region, given that the Gulf's huge amount of petrodollars essentially sustains the capitalist system. The first debate concerns the regional development of capitalism and the second concerns the progress of the world markets.

In brief, Hanieh focuses on the transformation of the Gulf powers, mainly Saudi Arabia, into a key player in the capitalist system following the end of World War II, as well the region's future role in preserving or changing the course of capitalist functioning.

Prior to defining the Gulf countries' roles in the capitalist order, the Capitalism and Class first analyses how Saudi Arabia, Qatar, the United Arab Emirates, Kuwait, Bahrain, and Oman politically and economically joined together to create the GCC, thus creating a capitalist actor in world affairs. The GCC's large-scale integration and impressive development in the regional sphere have undergone various phases, such as the emergence of a state-backed class formation within the contemporary world market. Hanieh first defines this class, stressing that it is a "set of social relations that emerge[d] around capital accumulation" (p.27). The process began with importing non-citizen workers (migrant labor) from Asian countries and disallowing them rights to possessions, citizenship, and legal defense options. This method quelled labor movements against such conditions because the countries could expel these workers at will to halt emergence of proletariat groups that would threaten the accumulation of capital.

In the first chapter of his book, Hanieh examines the formation of a capitalist class and capital accumulation in the Gulf, and then examines how oil contributed to the development of this capitalist class. Hanieh also discusses the imperialistic history of the region, which was dominated first by Britain and then by the US. At that time, the region was not aware of its resource potential and the role it could seize in the capitalist system. As Hanieh notes, the beginning of the oil age in the 1920s motivated Britain to keep the Gulf states under its rule, triggered US interest in the Middle East, and was a turning point in the region's class formation and internationalization. "Strong trading families and their cooperative relations with the imperialist powers were determining the course of the Gulf" (p.45). State and class formation in the region was an intertwined process, resulting in members of privileged families becoming part of the capitalist class.

"Limiting the explanation of the development of the Gulf region to oil-related relations would be insufficient in explaining the region's path, which was also shaped by global capitalism" (p.54). The essence of this class consciousness is linked to the accumulation of capital, which also led to state formation. Another step in this process was the internationalization of capital, which led to the global penetration of Gulf capital, creating powerful competition among capitalists for more shares.

In the 1950 s, the US was the dominant power in the international capitalist system, controlling $60 \%$ of the industrial product market in the 1950s. The Gulf region was among the source of this wealth, through oil revenues that international consortiums controlled in US interests. Leadership in the US at that time became increasingly focused on the Gulf's

${ }_{4}$ The Monthly Review first "used the term 'financialization' of US capitalism, pointing out that employment in the financial sector, trading volumes in the speculative markets and the earnings of Wall Street firms were all rising sharply,"(Foster and 
inclusion into the global order so as to continue the accumulation of capital. "By the 1960s, the US controlled over $60 \%$ percent of oil resources in the Middle East and had markedly increased its oil-related production efforts" (p.78).

The 1970s heralded a new period in the global economy. A decline in US power caused by the collapse of the Bretton Woods system ${ }^{5}$ decreased American influence over the oil-rich Gulf. The financialization of capitalism in the Gulf meant the mobilization of multinational corporations there and more involvement of the Gulf in the capitalist system. Then, a rise in oil prices sharply increased the Gulf countries' oil revenues, which recycled petrodollars into the financial system, providing a flow of these funds to the US and European financial and debt markets, keeping the capital market vibrant. In a demonstration of the Gulf's cooperation with the US-led capitalist economic order, Saudi Arabia especially used petrodollars to maintain the value of the US dollar (USD) via US Treasury purchases. Hanieh states that "the Organization of Petroleum Exporting Countries (OPEC) funneled 10\% of its total reserves (107 billion USD) into the US and European markets between 1973 and 1977" (p.87). This situation thus enhanced relations between the US and GCC states, and maintained the power of the US.

Hanieh defines GCC capital as Khaliji (Arabic for 'of the Gulf') capital, formed mostly through economic deals among the Gulf states. This capital, along with US capital, helped finance the First Gulf War, playing a salient role in what had been designated the New World Order by then-US President George H. Bush. From the Marxist perspective, the enrichment of a Khaliji capitalist class and strong state control over oil production and distribution overlapped with the process of state and class formation in the Gulf states at that time. The circulation of capital and commodity, importation of industrial goods and other items, the establishment of shopping malls, the increased interdependency of the US and the GCC region, and the importation of military equipment created an alliance between the two powers during the 1980s and 1990s. In an attempt to enhance regional integration of the GCC, Saudi Arabia began a new banking system, decreasing the role of foreign shares and control and ensuring a high level of domestic control.

Discussing circulating capital's effects on the formation of state and class in the Gulf, Hanieh also argues that "[o]il production allowed [the] GCC, as the main supplier of raw material and energy, to understand the importance of oil, contributing to US hegemony through dominating the Gulf' (p.133).

In the fourth chapter, Hanieh discusses the role of other global actors in the capitalist system, such as China, in the creation of "the sole global capitalist economy" (p.135). The basic characteristic of the emerging system was a salient development in the finance sector: building a world market based on global manufacturing and global distribution meant a new stage of internationalization. Emerging financial markets played an important role in this internationalization, which was determined by the flow of private capital throughout the world. Hanieh especially emphasizes that the emergence of new economic powers

\footnotetext{
"The Bretton Woods system of monetary management established the rules for commercial and financial relations among the world's major industrial states" in 1944. This "system was the first example of a fully negotiated monetary order intended to govern monetary relations among independent nation-states.... The chief features of the Bretton Woods system were an obligation for each country to adopt a monetary policy that maintained the exchange rate by tying its currency to the US dollar and the ability of the IMF [International Monetary Fund] to bridge temporary imbalances of payments.” In 1971, the system collapsed. (http://en.wikipedia.org/ wiki/Bretton_Woods_system)
} 
challenged US dominance by creating competition in the GCC region, threatening the supply of hydrocarbon products at the core of the capitalist development that the US had shaped and directed in accordance with its interests. In an attempt to compete with the US and the Western powers, China focused on substantial economic development, resulting in increased demand for oil. At the same time, the US pushed for free-trade agreements and free-trade regions with the GCC states for easier access to their resources. Despite the competition, GCC countries still directed a significant amount of their petrodollars to US treasuries, real estate, and bonds, setting the stage for financial bubbles and finally, an economic crisis.

Internationalizing the regional Khaliji capital developed strong ties among the GCC states through single-currency and common-rate policy goals via ongoing negotiations scheduled to be concluded by 2015. So far, Saudi Arabia, Kuwait, Bahrain, and Qatar have reached a settlement to form a common central bank with a unified currency. ${ }^{6}$ Combined with increasing oil prices, these developments have meant increased capital and more investment in Western media and telecommunication sectors. Hanieh explains, however, that this regular flow of capital has been interrupted by and partly caused the 2008 economic crisis. The burst of the mortgage bubble in the US resulted in huge losses for the GCC region because of its many financial assets there. However, the GCC has managed to overcome these setbacks through regional cooperation and by regularly increasing oil prices as well as giving state funds and credits to private banks and corporations, and even public corporations. Saudi Arabia, the leading GCC country, provided financial support to less-resistant economies such as Kuwait and Qatar. "Abu Dhabi gave \$10 billion to Dubai in 2009 in an effort to help its neighbor to overcome the negative effects of [the] crisis" (p.243). Another way of coping involved internationalizing the Gulf's construction corporations. These measures led to the development of a pan-GCC unification scheme to connect the Gulf via common policies.

Hanieh's arguments regarding the overlapping and interacting structure of regional GCC capitalism and global capitalism allows readers to understand how a capitalist system functions, proving the insufficiency of solely national or regional evaluations in understanding the global capitalist order. It offers a detailed analysis of the capitalist system at the regional and international levels.

\section{The Endless Crisis: How Monopoly-Finance Capital Produces Stagnation and Upheaval from the USA to China, John Bellamy Foster and Robert W. McChesney}

John Bellamy Foster and Robert W. McChesney offer a clear explanation of the current global economy, which, since the 2008 crisis, has been called the "Great Financial Crisis" (p.8), and is an extension of the slowdown in the world economy that has been occurring since the 1970s. The authors agree with Hanieh that the current crisis is related to the internationalization of monopoly capital, which has been felt deeply since 2008. "The main consequences of the internationalization of monopoly capital for accumulation are the intensification of world exploitation and a deepening tendency to stagnation" (p.128), meaning that a very small percentage of groups control most of the world's assets.

The authors focus on the changing nature of economic activity after the 1980s, moving from production to financialization and monopolization. For them, the US financial crisis

6 "Gulf Countries Take Steps to Achieve Monetary Unity, Al Monitor, http://www.al-monitor.com/pulse/business/2013/12/ gulf-gcc-monetary-union-central-bank.html\#. 
began in 2000, with the "bursting of the New Economy stock market bubble" (p.13). Defined as a budgetary and private sector crisis, and incorporating a decline in wages and an increase in unemployment, this stagnation has been accompanied by social and political unrest. China is also suffering from this crisis despite its relative development towards stability. Capitalism requires consistent growth and employment, and thus the current situation is a symbol of an "endless crisis" because the system is functioning on the basis of monopoly-finance capital, meaning that it is controlled by monopolistic corporations. This situation can only lead to stagnation, through "price markups of these corporations, giving rise to a growing problem of surplus capital absorption" (p.31). Bellamy and McChesney discuss the current economic crisis, which occurred under the US-led capitalist system, and describe it as the "failure of neoliberal economic policy, including Europe and Japan" (p.8), arguing that economic slowdown extends back to the 1970s, especially in the US. Despite huge military spending, a dollar-centered economy allowed the country to establish a hegemonic order, observed during the housing crisis in the 2000s. The two scholars point out that financialization created the conditions for an economic crisis, arguing that the term 'capitalism' was replaced with the term 'market economy' in an effort to hide the crisis. "The problem was not that no one saw the Great Financial Crisis coming, rather the difficulty was that the financial world, driven by their endless desire for more, and orthodox economists, prey to the worship of their increasingly irrelevant models, were simply oblivious to the warnings of heterodox economic observers all around them" (p.18). For a better understanding of the financialization of US capitalism, one must understand its features: "Employment in the financial sector, trading volumes in the speculative markets and the earnings of Wall Street firms were all rising sharply. Between 1980 and 2000, financial industry profits rose from $\$ 32.4$ billion to $\$ 195.9$ billion" (p.19). Along with financial speculations, more spending and more economic growth occurred. Because monopolistic corporations controlled surplus capital and could not find fields for investment, the economy became dependent on state spending as well financial expansion. Investments in foreign countries were also not enough to overcome the crisis that US economic hegemony suffered. Overaccumulation thus led to a slowdown in growth, one of the reasons for stagnation. The book emphasizes a point that many observers also note, which is that the US economy began its slowdown in 1970 due to the Vietnam War, excessive use of oil, and massive military build-up because of the Cold War. Attempts at mending that crisis included growing debt and credit as a symbol of a financialized economy.

The Triad (the US, Europe, and Japan) was thus in a "stagnation-financialization trap" (p.25) and tried to get out of it by exploiting developing countries for more profit, which only worsened the world economy. The 1980s and 1990s were defined by economic booms due to financial speculation led by rising debt, especially in the private sector. Production-based economic activity was replaced with speculative finance, leading to luxury consumption. According to the authors, decline in production resulted in unemployment in the Triad, and resulting in economies dependent on financial activities. Thus, the main reason for the stagnation was a price increase led by monopolistic corporations preventing surplus capital absorption.

Foster and McChesney argue that a monopoly in power, profits in great economies, and centralization of global capital are symbols of monopolization, adding that "total annual revenue of the five hundred largest corporations in the world was equal in 2004-08 to around 40 percent of world income, with sharp increases since the 1990s" (p.32). Additionally, price 
warfare and harsh competition among these oligopolistic corporations excluded small firms, in what is called "the monopoly stage of capitalism" (p.34).

The tendency towards firm monopolization and labor exploitation to increase income shifted the US' economic course towards more deficits, shaking all balances in all economic activities, turning the country into the world's largest borrower, and undermining its economic hegemony.

The book discusses the three phases of the global accumulation of capital: the mercantilist era, the industrial revolution, and monopoly capitalism, the last meaning the concentration of capital in parallel with emergence of the rich-North/poor-South division. The rise of China and India can be explained via exploitation of the working class, ultimately restricting the movements of capital, and putting the countries of the southern hemisphere under pressure.

In discussing the decline in US economic power, the book focuses on "the decline of the sociological foundations of entrepreneurial capitalism with the rise of the modern corporation and state" (p.50). After the 1970s, the situation in the global economy, especially in developed countries, signified a full-scale crisis. A salient shrinkage in the real growth rate of the US economy until 2008 caused the worst economic crisis since the Great Depression. The financialization character of economies bred stagnation. While capital was trying to find a way out of the growing surplus, financial institutions were mobilized across the world by a system that caused more debt.

This system opened the way for state intervention to bail out monopolistic corporations, promoting financial bubbles such as what occurred on Wall Street during the development of communication technology. But this 'solution' further undermined economic systems and created more stagnation. The book notes how quickly financial institutions became significant in the US economy: "As recently as 1990, the ten largest US financial institutions held only 10 percent of total financial assets; today they own 50 percent" (p.53).

Transitioning from monopoly capital to "monopoly-finance capital" based on exploitation and limiting rights such as insurance and wages meant a "debt burden" (p.55) on developing countries. This situation also burdened the US economy because it forced state-run institutions to spend trillions of dollars to bail out financial firms. Printing money contributes to more deficits, harming a currency's value. According to The Endless Crisis, a new hegemonic structure is rising in China because of capitalist growth, but it is not resolving the stagnation of the core countries because that structure is also based on sweeping financialization. "Accumulation - real capital formation in the realm of goods and services - has become increasingly subordinate to finance. Financialization can be defined as the long-run shift in the center of gravity of the capitalist economy from production to finance" (p.59). Marx foresaw the concentration of products that occurred in the nineteenth century, and the main factor in the shift away from that model was the modern credit system. This change resulted in a more visible division between real and monetary economics.

Financialization also brings a 'speculative economy,' where a crisis causes a contradiction because the finance sector experiences huge profits but economic growth suffers due to a decline in production. While finance, insurance, and real estate (FIRE) increased wealth among the upper class and spending among the middle class, debt as a cure to economic stagnation means a crisis in the long term.

Foster and McChesney explain the situation as follows: "Hence, financialization, while boosting capital accumulation through a process of speculative expansion, ultimately 
contributes to the corrosion of the entire economic and social order, hastening its decline" (p.70). The authors stress that the "extreme free-market" (p.79) is the reason for today's economic crisis, and they call this era the "new phase of financial imperialism" (p.71). Largescale social and economic disparity has resulted from this crisis, leading to a war-prone and environmentally damaged world.

Monopolies control most sectors, with huge corporations operating in most industries. Two hundred US firms have a monopoly over the total business profits in the US economy, and data reveals that these corporations' profits increased from $13 \%$ to $30 \%$ between 1950 and 2007, contributing to the mobilization of monopolies across the globe (p.81). The US auto industry is a good example of this trend. Technology also made its accession into world markets. In an important finding, the authors argue that an "increased degree of monopoly/ oligopoly would not only be to concentrate economic surplus in monopolistic firms but would also increase the rate of surplus value at the expense of wages" (p.94), leading to overaccumulation and stagnation. In the monopolistic world economy, competition has not totally disappeared but its nature has changed. After World War II, as a result of an increasing labor force, competition concentrated on labor costs instead of on low-cost policies. When monopolies reached their peak in the 1980s, huge layoffs occurred, defined as 'increasing efficiency' to deflect criticism against the functioning of capitalist system. Harsh competition among the giant corporations weakened some sectors in the US by breaking their "oligopolistic characteristics"(p.106).

Regarding the internationalization of monopoly capital, the book argues that this phenomenon really only emerged during the 2008 economic crisis. Although the neo-liberal perspective claims that the era of monopoly is over, monopolists avoid using the term 'defeat' and talk about a new era defined by "global monopoly-finance capital in production" (p.120). In the service sector, for example, many airlines have merged, and even Microsoft has made alliances with several corporations. It is not easy to understand the process leading to oligopoly rivalry because the issue is usually only considered from a national point of view; the concepts should be reviewed from an international perspective. It is also wrong to assume that market competition has weakened the power of monopolies/oligopolies. Foster and McChesney argue that the giant firms followed the divide-and-rule strategy, especially in the global South, which gave them advantages over smaller corporations.

The Endless Crisis considers the tendency towards monopoly as an attack on democracy, barring people from creating alternative power structures. Wealthy states act as supporters of monopoly capital while neo-liberalism proponents aim to remove all limits such as the political and economic barriers set by these states. Poorer states open to international interventions and directives from the IMF and the World Bank are exploited by giant corporations.

The Endless Crisis also focuses on the changing features of the "capitalist labor force" (p.135) after capitalism's production center was moved to developing countries (especially China and Eastern Europe) to take advantage of cheap labor, lower production costs, and easy access to domestic materials. "The South's share of industrial employment has risen dramatically from 51 percent in 1980 to 73 percent in 2008" (p.133). Thus, exploitation of labor by monopolistic firms paying low wages has allowed corporations to make huge profits. Paradoxically, the work force was "redundant" (p.141) during crisis periods, and people were forced to work more for less money. For more accumulation, more mobilization of labor was necessary. This form of reshaping world production and repositioning labor began in 
1970 with globalization, which emerged after World War II via the expanding activities of international corporations and gained momentum with the collapse of the Soviet Union. For instance, some US firms have more workers in developing countries than they do in the US, which is why capital accumulation was at its highest level while labor wages remained low. This situation made China and other Asian countries vulnerable to big corporations' cheap labor politics and increased migration from rural areas to cities, as people sought work. Cheap labor also contributes to protecting the value of money, allowing the capitalist class to retain their financial assets. Capitalist accumulation also increased through temporary workers who migrated (legally and illegally) to core countries in exchange for (low) wages.

Foster and McChesney consider the age of the internationalization of monopoly capital and the movement of world production to the South a "new imperialism" (p.75). This shift has resulted in emerging economies with high growth rates, such as China. But the process has different characteristics than what occurred in developed countries because of the millions of people who work as cheap labor. Still, China is expected to achieve the next level of capitalism based on its "capital-intensive" (p.158) manufacturing rather than its labor army. Although these emerging economies are also open to the crises that Western capitalism is experiencing (for example, China's export markets are struggling), there is speculation that the Chinese economy will be the world's largest by 2020 (p.149), something "[v]iewed with unease in the old centers of world power" (p.162). Considering these predictions, the authors note that China may offer temporary relief from the current economic impasse, as the US did for 30 years with the financialization trend, but nothing permanent. The path that the Chinese economy is on is based on human exploitation, land grabbing, and creating rich strata. Despite this early stage of capitalist transformation, today China is the world's "final production platform" (p.175), alluding to the fact that many countries no longer use goods as their main sources of revenue, but rely on financial mechanisms. The Endless Crisis defines China as "more the world assembly hub than the world factory" (p.175), and considers great growth in the Chinese economy as the "product of a global system of exploitation and accumulation" (p.179). There are varied predictions regarding whether China will provide a solution to the current crisis; at this point, it is logical to assume that the futures of China and the West are tied together in many respects.

\section{Ending the Crisis of Capitalism or Ending Capitalism?, Samir Amin}

Samir Amin considers that while accumulation is the core element in the continuity of capitalism, it also provides the means for struggling against it. "Atlantic capitalism" (p.1) has been built on the ground of violating the rights of the majority to benefit the privileged rich strata. Although globalization declared triumph with the unipolar world, "liberation struggles" (p.59) in Asia, Africa, and Latin America symbolize the first challenges against the capitalist order, as capitalism aims to maintain its dominance through exploiting people and resources in periphery countries via oligopolies.

Amin argues that the energy crisis that the world is suffering is not because of a lack of oil but because of oligopolies' policies to assume control over oil resources by excluding other actors. Despite attempts by oligopolies to access resources, resistance, especially from the South, will rise against them. Rather than being financial, Amin states that the current crisis is a "crisis of the imperialist capitalism of oligopolies whose exclusive and supreme power risks being questioned by the struggles of the entire popular classes and the nations of the 
peripheries" (p.3). It is also about the decline of US hegemony.

Amin, like the other authors, maintains that the current economic crisis dates back to the 1970s, with the collapse of dollar-based system. Capitalism, then, is facing a systemic crisis rather than a financial crisis. Financialization, with oligopolies assuming control over markets, also damages democracy because of the concentration of power among these oligarchs. Instead of competing with each other, the US, EU, and Japan have created a collective imperialism directed against the rest of the world.

Amin argues that the in-crisis US hegemony aims to resolve its crisis by using the war machine against the poor South in an effort to reach more resources, as it has continually done throughout capitalism's history. If this strategy fails, the author asks the following question: Who will replace the current hegemon? China is not the right answer because its "strategy is confined to promoting a new globalization without hegemony" (p.12). The only satisfying alternative, then, is a collobaration of the countries of the South.

Ending the Crisis also discusses how the military apparatus of capitalism conceals itself in organizations such as NATO and under pretexts such as the war on terror to bypass the United Nations. For this reason, there is need for "[e]mancipatory struggles, a questioning of the system exclusively by some of its peripheries" (p.16). Another kind of struggle against the capitalist order is to use all gains to defeat the system's military tool. This approach, Amin maintains, should be an international collective act; nationalization can overcome oligopolies in developing countries.

Amin considers the current financial collapse as the end of the capacity of capitalism to evolve, which has led to a systemic crisis. The positive atmosphere that the post-World War II era created for the accumulation of capital has now disappeared. A system based on bipolarity, such as existed with the US and the Soviet Union, represented two separate ideologies and economy models for the world and has lost its viability. Prior to this development, monopolies' delocalized feature allowed them to create low real-wage policies and privatization, an important step for accumulation and expansion across the globe. Today, the crisis of accumulation, energy-linked problems, food crises (which may be the most important in all of these), and the impossible continuation of the order that capitalism has created, clearly reveal that a systemic crisis exists. In an effort to cope with this awakening in the South, the hegemonic order may use more force, creating "apartheid at the world level" (p.161). Today's capitalism is defined by financialization abandoning the supply-anddemand reality and acting through economic agents so as not to be affected from market ups and downs. The author argues that the inner problems of the accumulation system and the pressure that it created in society over the direction of change brought stagnation. The question now is whether society can develop an alternative to the current order. Unless the oligopolistic characteristics of the system are changed, total recovery of the financial markets will be impossible.

Amin, tracking capitalism's development, distinguishes between the European and Chinese paths, arguing that access to land determined how capitalism advanced. European capitalism, also known as historical capitalism, banned the rural population from accessing land. On the other hand, Chinese capitalism allowed for access to land as a main state principle. The former path encompasses the often-violent methods used in imperialist capitalism. China closed itself to the capitalist world for some time, and this relatively slower path offered advantages in terms of cheap labor and a large workforce. For Amin, individual interests 
mixed with competition underlie capitalism. At the same time, "[a]ccumulation through dispossession is a permanent feature in the history of capitalism" (p.51). Through conquest of the world, Europe dispossessed natural resources as a way of historical capitalism, leading to accumulation.

Amin also points out capitalism's characteristic that does not allow the periphery to be at the centre, and posits that societies on the periphery should cut ties with capitalism to create an "alternative globalization." In this regard, the twentieth century marked "the first wave of socialist revolutions and the awakening of the South" (p.59). Capitalism through the cooperation of the Triad has a complex structure and many mechanisms operate against the periphery through organizations such as the World Bank, the World Trade Organization, etc. The US hegemony exerts military control in an organized "collective imperialism" (p.109). Ending the Crisis states that continuing North/South conflict is inevitable, but unless a major change such anti-capitalist revolutions occur in the capitalist world, a socialist formation is not possible. Today, some societies of the South are developing alternatives to monopolies and product technology in an effort to overcome dependency. The Chinese revolution in 1949 struggled to create an alternative to imperialist capitalism, then gradually evolved towards capitalism. Societies of the South, such as Yemen, Pakistan, and Afghanistan fought for freedom from capitalist exploitation, despite their limited military resources and fragility due to the lack of a powerful central authority. During such struggles, democracy should be internationalized because, due to its changing structure. it means more than "a static and definitive" formula.... Democracy is about all aspects of social life and not exclusively the management of the political life of a country" (p.90). However, defining democracy with a free market, as capitalism has done, reduces it to the US-style democracy that socialism is against.

In the fifth chapter, Amin focuses on capitalism's practices of agriculture and emphasizes the necessity of land tenure reform in the South. By means of the division of labor between producers and companies, agricultural production is very high in the North compared to the South: "modern family agriculture constitutes an inseparable part of the capitalist economy" (p.101). The South has failed at attempts to develop similar agricultural practices due to the lack of that division of labor and a lack of democracy, among other reasons. Nations reacting to monopolization should work towards a regulation between the markets and "peasant agriculture" (p.141) and protecting national production should be foremost so that the price monopoly is removed. This method is termed 'food sovereignty,' which has become a calamity in Africa. Amin discusses the Triad's awareness of the issue via systematic policies. Because industrialization and food security are vitally linked, the South must also address this issue. With the 2008 financial crisis, the food deficit arises as a critical problem for all states. "China and Vietnam provide a unique example of a system for managing access to the land which is neither based on private ownership, nor on custom, but on a new revolutionary right, which is that of all the peasants having equal access to land" (p.115).

In the sixth chapter of Ending the Crisis, Amin explores two paths of development: humanitarianism and internationalism. He first criticizes the North's oversimplification of the reasons for underdevelopment and how it deals with the problem from the perspective of the economy and ignores the social dimensions. For Amin, "[d]evelopment is an overall process that involves the definition of political objectives and how they are articulated: democratization of society and emancipation of individuals" (p.131). 
In essence, the nature of a socialist revolution is internationalist, but a tendency towards humanitarianism is clearly seen. A rhetoric used by the dominant discourse tries to explain underdevelopment through the division of good and bad governance by eliminating some of the main discussion points such as the role of civil society, social justice, and the fight against poverty. For instance, to neutralize civil society and social forces, foreign aid is used to corrupt the leading strata, especially in Africa. Therefore, aid from rich states should be allocated via the UN, making the main struggle tool solidarity not humanitarianism. Amin calls this method the "alternative aid" (p.140) process because it excludes all capitalist formations, such as the OECD and the World Bank, leading to the creation of alternative developments "giving priority to internal markets (national and regional)" (p.143). Alternative cooperation models can be developed, such as a South-South cooperation that could replace the NorthSouth pattern of using technology to assume control over natural resources.

The last chapter of Ending the Crisis more addresses the philosophical discussion around the topic, explaining the ideology of socialism and Marx's contributions to the field by focusing on the change and transformation of societies towards a better system. Putting the idea of emancipation at the centre, a transition period can result in either revolution or chaos (which outcome is not clear). Amin defines the current system as a "liberal virus" (p.14) with "[w]ork and exploitation, commercial alienation and expansion, the fetishism of money, the state at the service of capital" (p.159) as its main features. The ongoing tension between the North and South has recently increased in the race to control the natural resources of periphery countries. This section focuses on discussion around creating a socialist alternative to the current capitalist system and on the methods for such a process by defining today's state as an apparatus of capitalist oligopolies. The question arises whether the current financial crisis could be a transition into an alternative to the current system. At this point, "[c]areful analysis of the strategies of the oligarchy in the Triad, the economic interests at stake and the geopolitics and geostrategy of states that are systematically on the defensive" (p.171) is a must.

Amin concludes that the current path of capitalism will move the world towards chaos unless a socialist revolution is realized. Here the importance of an ideological battle emerges; lacking awareness, the South's fate is to subordinate to the North.

\section{Conclusion}

The three books agree on one point: the capitalist world economy faces a serious downfall, allowing for the probability of the rise of new powers/systems in different parts of the world. Regardless of who these emerging powers are or which ideologies struggle against the US-led capitalist world order, this situation also means the decline of US hegemonic power, which not only dominates the global economic system, but also the dynamics of capital markets. John Bellamy Foster and Robert W. McChesney's The Endless Crisis: How Monopoly-Finance Capital Produces Stagnation and Upheaval from the USA to China puts forward that China is the emerging power, while Adam Hanieh's Capitalism and Class in the Gulf Arab States discusses the rise of the Gulf region as an alternative to American economic domination. Hanieh emphasizes a rising Chinese effect in the region and a decline in US hegemony as it loses control over Gulf capital, and Foster and McChesney note a relative setback in US power due to China's rising economic power. It might be said that historical capitalism (to use Amin's phrase in Ending the Crisis of Capitalism or Ending Capitalism?) 
will lose ground against new capitalist powers. However, it is not clear whether China's rise will provide for a recovery of the global economy. Amin's take on the crisis of neoliberal politics and capitalism calls the issue a systemic crisis. Like Foster and McChesney, Amin points out that the monopolistic/oligopolistic tendencies in the world economy have led the system to the deepest crisis it has ever experienced. Like all the other authors, Amin argues that the US, Europe, and Japan are at the center of this crisis and that they will be the countries most affected by this economic setback. While Hanieh maintains that Gulf capital has a determinative role in the capitalist rivalry regardless of whether it cooperates or conflicts with US power, Amin focuses on the developing or periphery countries as producers of alternative political and economic structures through concrete movements towards global emancipation.

\section{Bibliography}

"Gulf Countries Take Steps to Achieve Monetary Unity." Al Monitor. http://www.al-monitor.com/pulse/ business/2013/12/gulf-gcc-monetary-union-central-bank.html\#.

Amin, Samir. Ending the Crisis of Capitalism or Ending Capitalism? New York: Pambazuka Press, 2011.

Foster, John Bellamy and Robert W. McChesney. The Endless Crisis: How Monopoly -Finance Capital Produces Stagnation and Upheaval from the USA to China. New York: Monthly Review Press, 2012.

Hanieh, Adam. Capitalism and Class in the Gulf Arab States. New York: Palgrave Macmillan, 2011. 